\title{
ANAESTHESIA FOR INTRA-LARYNGEAL LASER SURGERY
}

\author{
Halappa N. Konchigeri, M.B.B.s., and Mohamed H. Shaker, M.D."
}

\section{INTRODUCTION}

The Laser (Light Amplification by Stimulated Emission of Radiation), was first introduced into medicine about a decade ago, and within this relatively short time, has added a new dimension to medical science. A variety of substances (solids and gases) can stimulate laser emissions. Lasers vary in wavelength and physical properties. These variations make them useful for a variety of clinical and investigational purposes. Some lasers are selectively absorbed by different tissues in the body. In contrast, the carbon dioxide laser is almost completely absorbed by all the tissues in the body. ${ }^{1,2,3,4,5,6}$

The carbon dioxide laser currently used was first developed in 1965. Its potential as a surgical tool was recognized early, leading to the development of the laser endoscope and the stereomicroscope laser attachment. ${ }^{7}$

The recent introduction of the carbon dioxide laser for intralaryngeal surgery $8,0,10$ has posed a number of challenging problems for the anaesthetist for the skilful and judicious anaesthetic management for this kind of surgical procedure.

The advantages claimed for laser surgery over conventional techniques are localized destruction of tissue to precisely controlled depths with minimal bleeding, insignificant tissue reaction, and rapid recovery. ${ }^{?}$

This presentation outlines our experience in anaesthetic management and the precautionary steps to be taken during intralaryngeal operations, in the light of currently available clinical data.

\section{Materials and Methods}

Thirty patients between 4 and 69 years of age, in physical status I, II or III, underwent laser surgery of the larynx for laryngeal lesions listed in Table I. The group consisted of 20 male and 10 female patients.

\section{Preoperative evaluation}

Each patient scheduled for operation was evaluated specially for the type and extent of the laryngeal lesion and the degree of laryngeal obstruction on the basis of past surgical history, findings at indirect and direct laryngoscopy and on X-ray examination.

\section{Preoperative laboratory studies}

All patients had routine laboratory studies including haematology, urine analysis, and chest X-ray. Special investigations such as electrocardiogram, sickle cell studies, and serological data were obtained when the situation warranted.

\footnotetext{
${ }^{\circ}$ University of Illinois Hospital, Department of Anesthesiology, 840 South Wood Street, Chicago, Illinois, 60612 .
} 
TABLE I

\begin{tabular}{lcccccc}
\hline \hline Lesions of Larynx & \multicolumn{3}{c}{$\begin{array}{c}\text { No. of Patients } \\
\text { Oho Received Laser }\end{array}$} & $\begin{array}{c}\text { Total No. } \\
\text { of Lasers }\end{array}$ & $\begin{array}{r}\text { Total No. } \\
\text { of Patients }\end{array}$ \\
\hline Papilloma & 10 & 5 & 1 & 23 & 19 \\
Polyp & 8 & 1 & - & 10 & 9 \\
Hyperkeratosis & 1 & - & - & 4 & 2 \\
Vocal nodule & 1 & - & - & 1 & 1 \\
Carcinoma in situ & 2 & - & - & 2 & 2 \\
$\quad$ Total & 22 & 6 & 2 & 40 & 30 \\
\hline
\end{tabular}

\section{Premedication}

Patients received atropine, with or without the addition of a barbiturate, a tranquilizer, or a narcotic.

\section{Anaesthretic Management}

The mouth, pharynx, and larynx were carefully sprayed with 4 per cent lidocaine prior to induction of anaesthesia. Following pre-oxygenation, anaesthesia was induced with a sleep dose of 2.5 per cent thiopentone solution. Succinylcholine, $1 \mathrm{mg} / \mathrm{Kg}$ was then administered to facilitate the tracheal intubation. After complete jaw relaxation, a pre-tested well-lubricated, small red rubber cuffed oral tracheal tube was gently introduced into the trachea. The size of the tracheal tube ranged from $3.5 \mathrm{~mm}$ to $5 \mathrm{~mm}$ I.D. (No. 16 to 22 French). The cuff was inflated with just enough air to make contact with the tracheal wall. The tracheal tube was placed in such a way that the inflated cuff was well below the vocal cords, to avoid the cuff being accidentally hit by the laser beam. A small saline-soaked gauze pad was placed between the vocal cords and the cuff to avoid exposure of the anterior tracheal wall and the cuff of the tracheal tube to the laser beam. In children, inhalation induction with halothane in oxygen was chosen.

Anaesthesia was maintained with a total flow of 10 litres per minute consisting of nitrous oxide 7 litres and oxygen 3 litres into a circle absorption system. Small supplemental doses of fentanyl or halothane (0.5-0.75 per cent) were administered as required.

Succinylcholine, d-tubocurare or pancuronium were used to maintain muscle relaxation during the entire procedure to prevent coughing, bucking, and untimely movement of head and neck. Succinylcholine was administered to 22 patients either in intermittent doses of 20 to $40 \mathrm{mg}$ or as a 0.1 per cent intravenous infusion, the flow being adjusted to maintain continuous relaxation. Six patients received d-tubocurare. After an initial dose of 15 to $20 \mathrm{mg}$, the addition of 3 to $6 \mathrm{mg}$ at intervals of 20 to 30 minutes provided adequate muscular relaxation. Pancuronium was used in 8 patients in an initial dose of 5 to $8 \mathrm{mg}$ followed by $1 \mathrm{mg}$ supplemental doses administered as required. The lungs of all patients were ventilated manually to maintain adequate ventilation.

Anaesthesia was discontinued at the end of the operation. Any residual effect of non-depolarizing muscle relaxants (d-tubocurare or pancuronium) was re- 
versed with prostigmine $(0.04 \mathrm{mgs} / \mathrm{kg})$ in combination with atropine $(0.02 \mathrm{mgs} /$ $\mathrm{kg}$ ). The trachea was extubated on the basis of clinical assessment for complete recovery from the residual effect of the muscle relaxant. In some instances a peripheral nerve stimulator was used. Oxygen was administered by face mask for 3 to 5 minutes thereafter and patients were observed for possible laryngeal obstruction prior to their transfer to the recovery room.

In the recovery room, patients received humidified oxygen ( 40 per cent) by face mask and vital signs were carefully monitored for 1 to 2 hours, before they were discharged from the recovery room.

\section{Patients with Tracheostomy}

These patients were advised to clear the airways by coughing. The trachea and the stoma were sprayed with 4 per cent lidocaine and a well lubricated red rubber cuffed tracheal tube of adequate size was placed in position. The remainder of the anaesthetic management was as described.

\section{Monitoring and Measurements}

Heart rate, blood pressure and oscilloscope electrocardiographic monitoring were done in all patients. In five of them blood gas determinations were done to evaluate the adequacy of ventilation. Blood samples were collected prior to anaesthesia and approximately 30 minutes after establishment of controlled ventilation.

\section{Laser Apparatus and Surgical Techniques}

The apparatus consists of a lasing chamber $1.3 \mathrm{M}$ long with water cooling and a system of tubing encasing mirrors and joints which carry the laser beam to the endoscope attachment. ${ }^{9}$

After the patient was anaesthetized, the larynx was exposed with the JakoBilling laryngoscope which was then placed on the suspension apparatus. The microscope along with the laser attachment were positioned to bring into view the localized area of the larynx with the lesion. The aiming light for the laser beam was adjusted with the joystick control on the laser attachment and the laser was then activated.

\section{Results}

The duration of anaesthesia varied between 45 and 165 minutes, with an average duration of 113 minutes. Induction of annesthesia was satisfactory in all patients. Muscular relaxation provided by succinylcholine used either in small intermittent doses or as a continuous infusion was found to be adequate for the entire operation. However, constant attention was required to regulate the supplemental doses of the drugs. The total dose of succinylcholine used during operation ranged between 200 and $900 \mathrm{mgs}$ (average $477 \mathrm{mg}$ ).

D-tubocurare and pancuronium provided excellent working conditions. Because supplemental doses were needed at longer intervals (20 to 30 minutes), the anaesthetist could concentrate on the observation of vital signs. No significant changes were observed in these. 
TABLE II

Blood Gas Analysis

\begin{tabular}{|c|c|c|c|c|c|c|c|c|c|}
\hline \multirow[b]{2}{*}{ Patient } & \multirow[b]{2}{*}{ Age } & \multirow[b]{2}{*}{ Sex } & \multirow{2}{*}{$\begin{array}{l}\text { Endotracheal } \\
\text { Tube Size (Fr.) }\end{array}$} & \multicolumn{3}{|c|}{ Pre-operative } & \multicolumn{3}{|c|}{ Intra-operative } \\
\hline & & & & $\mathrm{PO}_{2}$ & $\mathrm{PCO}_{2}$ & $\mathrm{pH}$ & $\mathrm{PO}_{2}$ & $\mathrm{PCO}_{2}$ & $\mathrm{pH}$ \\
\hline 1 & 60 & $F$ & 20 & 69 & 40 & 7.39 & 96 & 37 & 7.43 \\
\hline 2 & 63 & M & 22 & 73 & 44 & & 112 & 38 & \\
\hline 3 & 20 & $\mathrm{M}$ & 18 & 89 & 39 & 7. & 138 & 36 & 7.44 \\
\hline 4 & 37 & $\mathrm{M}$ & 20 & 91 & 38 & 7.4 & 116 & 36 & \\
\hline 5 & 33 & $\mathrm{M}$ & 20 & 87 & 36 & 7.43 & 122 & 33 & 7. \\
\hline
\end{tabular}

Blood gas studies (Table II) confirmed that ventilation was adequate during the operation in spite of the small bore tracheal tube being used.

\section{Discussion}

In devising an anaesthetic technique to be used for carbon dioxide laser surgery of the larynx, the anaesthetist must be cognizant of the potential hazards of the surgical equipment, the anaesthetic requirements for the surgical procedure and above all the safety of both patient and operating room personnel.

It is essential to have a complete review of the patient's medical history and a thorough physical examination, including clinical assessment of the airways and findings on direct or indirect laryngoscopy with regard to the site, nature, and extent of the lesion. Extensive laryngeal lesions causing partial obstruction in the awake state may produce complete obstruction during induction of anaesthesia. In some instances the laryngeal anatomy is markely obscured (e.g., in multiple polyposis) and difficulties may be encountered in establishing an airway by tracheal intubation. Prior discussion of the problems with the otolaryngologist and consideration of elective tracheostomy or partial excision of massive lesions under local anaesthesia is vital to the safe anaesthetic management of the patient.

Any non-flammable anaesthetic agent may be used. Among the inhalation agents, halothane has the advantages of rapid induction, easy maintenance and smooth recovery, and so fulfills the essential criteria for an anaesthetic for laser surgery of the larynx. We have used halothane for induction and maintenance of anaesthesia in young children. However, patients with laryngeal lesions are likely to undergo repeated operations and this fact should be borne in mind in the selection of anaesthesia. Fentanyl was used as a supplement in those patients in whom repeated anaesthesia was a possibility. Enflurane may provide the samc ideal conditions as halothane. Methoxyflurane is less desirable because of prolonged induction and slow recovery.

Laser surgery of the larynx involves proper positioning of delicate and sophisticated equipment (laser attachment, Jako-Billing laryngoscope, etc.), so that only the localized tissue involved in the lesion is continuously under direct view during the process of lasing. Any attempt of coughing, bucking, movement of head and neck or the laryngeal musculature will be hazardous, not only because of disturbance of the equipment, but because it may produce a sudden shift in the laser beam and accidental destruction of normal tissue. 
The use of muscle relaxants to maintain continuous muscular relaxation will provide stability of the equipment and produce relaxed and immobile vocal cords for smooth lasing of the laryngeal lesion. We have used both depolarizing and non-depolarizing muscle relaxants. Succinylcholine, used either in intermittent doses or as a 0.1 per cent continuous drip, has the advantage of moment-tomoment control and freedom from problems of drug reversal at the end of the procedure. However, because of the time needed for completion of the operation, the large amounts of succinylcholine used increases the incidence of dual or phase II block. Another disadvantage is the need for constant attention to the supplemental doses or regulation of the rate of infusion of succinylcholine.

Efficient maintenance of the airway and controlled ventilation necessitated the use of small bore, cuffed red rubber tracheal tubes. Tracheal tubes of sizes $3.5 \mathrm{~mm}$ to $5.0 \mathrm{~mm}$ I.D. (No. 16 to 22 French), provided maximum working space for the otolaryngologists around the laryngeal inlet.

In vitro studies have shown ${ }^{11}$ that the laser beam can penetrate plastic tracheal tubes more readily than red rubber ones. Fire has occurred when the laser beam penetrated plastic tracheal tubes filled with oxygen. These studies prompted us to use red rubber tracheal tubes with a cuff to minimize the leakage of anaesthetic gases containing oxygen in the vicinity of the laser beam. Inflation of the cuff was also essential to maintain adequate control over the ventilation. To our knowledge, no specific studies have been undertaken to determine the potential risk of fire or explosion when the laser beam comes into contact with different concentrations of oxygen or anaesthetic gases. In our cases we have used $30 \mathrm{pcr}$ cent oxygen to minimize this hazard.

The tracheal tube cuff can easily be punctured by a single direct exposurc to the laser. ${ }^{11}$ Sudden rupture of the cuff will not only expose the anaesthetic gases in the vicinity of laser, but also will add a ventilatory problem in face of massive leakage of the anaesthetic gases from the trachea. Preventive measures against this hazard involve placement of a saline-soaked small gauze pad between the vocal cords and the tracheal tube cuff." This measure also protects the subglottic area and the anterior tracheal wall from exposure to the laser beam and consequent damage.

\section{Laser Hazards and Safety Precautions}

The carbon dioxide laser is absorbed by all biological tissues. The laser beam is $2 \mathrm{~mm}$ in diameter and creates intense heat in a small area so that the tissue is instantly vaporized and the bleeding points are coagulated. The beam is reflected by metal surfaces and absorbed by glass and plastics. The main hazards of the laser bean are due mainly to the high intensity of its light on normal tissues of the patient and on the personnel working in its vicinity.

All personnel in the operating room must wear safety eye glasses to protect the cornea from injury in case of accidental reflection of the beam from the metal surface of the surgical instruments. Patients' eyes should be equally protected by use of silvered plastic eye shields. ${ }^{612}$ The potential risks of the inhalation of the vaporized tissue at the site of the operation is yet to be determined, although a 
$2 \mathrm{~mm}$ self-retaining suction tip is clipped on the inner side of the laryngoscope for immediate removal of smoke and steam from the target area. ${ }^{6}$

Operating room personnel may also be at risk from chronic skin exposure to the laser. Safety codes are set down to make laser surgery safe for all personnel involved. Recommendations include the wearing of protective goggles by operating room personnel and the construction of laser operating rooms with walls which have low reflection properties. ${ }^{2,6}$

When the anaesthetist wears protective goggles his field of vision is reduced. The problem is further compounded by the darkened operating room. Consequently he has to be more alert in keeping a constant watch on flowmeters on gas supplies and in monitoring of vital signs. A small flashlight or some other light source should always be at hand during the operation.

\section{Summary and ConClusion}

Thirty patients received general anaesthesia for forty intralaryngeal operations using a laser beam. The essential requirements for the anaesthetic management are:

(1) Anaesthetic agents should be non-flammable.

(2) Small diameter red rubber cuffed tracheal tubes provide maximum working space for the surgeon, facilitate controlled ventilation and minimize the explosion hazard of anaesthetic gases in the vicinity of the laser beam.

(3) Continuous muscle relaxation of head and neck and of laryngeal muscles facilitates the instrumentation and lasing of lesions of vocal cords which are thus rendered fixed and immobile.

Preventive measures must be taken against accidental exposure to the laser beam of normal tissues of the patient and of personnel in the operating room.

\section{RÉSUMÉ}

Sous anesthésie générale trente malades ont subi une chirurgie du larynx avec emploi du Laser. Après induction au Thiopentone et Succinylcholine, les malades furent intubés avec un tube de caoutchouc de petit calibre ( 16 à $22 \mathrm{Fr}$ ) à ballonnet. L'intubation nous a permis d'une part d'assurer une ventilation adéquate et d'autre part de diminuer les dangers d'ignition des gaz anesthésiques au voisinage des rayons Laser.

L'anesthésie fut maintenue avec 70 pour cent de Protoxyde d'Azote supplémenté de Fentanyl ou d'Halothane. Les malades ont été maintenus curarisés afin d'éliminer des mouvements du cou, de la tête ou de la musculature laryngée.

Durant ces interventions tout le personnel doit porter des lunettes de sécurité afin de se protéger la cornée contre les réflections des rayons sur les instruments métalliques.

Cette technique d'anesthésie ainsi que les mesures de sécurité utilisées ont donné satisfaction. 


\section{ACKNOWLEDGMENT}

The authors gratefully thank Dr. A.H. Andrews, Jr., Department of Otolaryngology, Abraham Lincoln School of Medicine, for his help in the preparation of the manuscript.

\section{REFERENCES}

1. Goldman, L. \& Rockwell, R.J. Laser in Medicine, New York: Gordon and Breach, Science Publishers, Inc. (1971).

2. Goldman, L., Rockwell, R.J., \& FidLeR, J. Investigative laser surgery: Safety aspects. Biomed Engin. 4: 415 (1969).

3. Staff Report: Review and Outlook 1972. Laser Focus. 6: 23 (1972).

4. Lutz, A.M. Trends in laser applications. Am. J. Pub. Health 61: 2277 (1971).

5. Gonzalez, R., Edlich, R.F., Bredemeier, H.C., et al. Rapid control of massive hepatic hemorrhage by laser irradiation. Surg., Gyne., Obst. 121: 198 (1970).

6. BrRCH, A.B. Anesthetic consideration during laser surgery. Anesthesia \& Analgesia. 52: 53 (1973).

7. Polanyi, T.G., Bredemeier, H.C., \& Davis, T.W., Jr. A $\mathrm{CO}_{2}$ laser for surgical research. Med. Biol. Engin. 8: 541 (1970).

8. Polanyr, T.G., et al. Experimental $\mathrm{CO}_{2}$ laser surgery of vocal cords. Eye, Ear, Nose, Throat Mon. 52: 171 (1973).

9. Stronc, M.S. \& Jako, G.J. Laser surgery in the larynx: Early clinical experience with continuous $\mathrm{CO}_{2}$ laser. Annals of Otology, Rhinology, and Laryngology. 81: 791 (1972).

10. JAKo, G.J. Laser surgery of vocal cords. Laryngoscope (In Press).

11. ANDinews, A.H., Jr. Department of Otolaryngology, Abraham Lincoln School of Medicine, Unpublished Data.

12. Leibowitz, H.M. \& PeAcock, C.R. Corneal injury produced by carbon dioxide laser radiation. Arch. Ophthalm. 81: 713 (1969). 